Delmas R J, Ascencio J-M, Legrand M 1980 Polar ice evidence that atmospheric $\mathrm{CO}_{2} 20,000 \mathrm{yr}$ BP was $50 \%$ of present. Nature 284(5752): 155-157

Genthon $\mathrm{C}$ and 7 others 1987 Vostok ice core: climatic response to $\mathrm{CO}_{2}$ and orbital forcing changes over the last climatic cycle. Nature 329(6138): 414-418

Jouzel J and 6 others 1988 Climatic interpretation of a continuous deuterium profile obtained from the Vostok, Antarctica, ice core (160000 years). Annals of Glaciology 10: $206-207$

Jouzel J and 6 others 1987 Vostok ice core: a continuous isotope temperature record over the last climatic cycle (160 000 years). Nature 329(6138): 403-408

Lorius C, Jouzel J, Merlivat L, Barkov N I, Korotkevich Ye S, Kotlyakov V M 1985 A 150,000-year climatic record from Antarctic ice. Nature 316(6029): 591-596

Neftel A, Oeschger H, Schwander J, Stauffer B, Zumbrunn R 1982 Ice core sample measurements give atmospheric
$\mathrm{CO}_{2}$ content during the past 40,000 yr. Nature $295(5846)$ : $220-223$

Neftel A, Moor E, Oeschger H, Stauffer B 1985 Evidence from polar ice cores for the increase in atmospheric $\mathrm{CO}_{2}$ in the past two centuries. Nature 315(6014): 45-47

Pearman G I, Etheridge D, Silva F de, Fraser P J 1986 Evidence of changing concentrations of atmospheric $\mathrm{CO}_{2}$, $\mathrm{N}_{2} \mathrm{O}$ and $\mathrm{CH}_{4}$ from air bubbles in Antarctic ice. Nature 320(6059): 248-250

Raynaud D, Barnola J M 1985[a] An Antarctic ice core reveals atmospheric $\mathrm{CO}_{2}$ variations over the past few centuries. Nature 315(6017): 309-311

Raynaud D, Barnola J M 1985[b] $\mathrm{CO}_{2}$ and climate: information from Antarctic ice core studies. In Ghazi A, Fantechi R (eds) Current Issues in Climate Research; proceedings of the EEC Climatology Programme Symposium, Sophia Antipolis, France, 2-5 October 1984. Dordrecht, D. Reidel Publishing Co: 240-246

\title{
10BE CONCENTRATIONS IN ANTARCTIC ICE
}

\author{
by \\ J. Beer and $\mathrm{H}$. Oeschger \\ (Universität Bern, Physikalisches Institut, $\mathrm{CH}-3012$ Bern, Sidlerstraße 5, Switzerland) \\ and \\ G. Bonani, M. Suter and W. Wölfli
}

(Institut für Mittelenergiephysik, ETH, Zürich, Switzerland)

\begin{abstract}
Measurements of the cosmogenic isotope ${ }^{10} \mathrm{Be}$ $\left(\mathrm{T}_{t}=1.5 \mathrm{Ma}\right)$ on Greenland ice cores produced interesting results. Variations in the ${ }^{10} \mathrm{Be}$ concentrations can be interpreted in terms of changes in the production rate and in atmospheric circulation and deposition. During the Holocene, good agreement between short-term variations in ${ }^{10} \mathrm{Be}$ and ${ }^{14} \mathrm{C}$ indicates that the production rate of both isotopes was changing, probably due to solar modulation.
\end{abstract}

During the last ice age, periods with significantly higher ${ }^{10} \mathrm{Be}$ concentrations are observed. The good anti-correlation between ${ }^{10} \mathrm{Be}$ and $\delta^{18} \mathrm{O}$ suggests that these intervals correspond to periods of low precipitation rates.

Work on Antarctic ice cores is in progress, but only relatively few ${ }^{10} \mathrm{Be}$ data have been published yet. ${ }^{10} \mathrm{Be}$ results from Antarctic ice cores are presented and compared with data from Greenland.

\section{STUDIES ON THE BASAL-ICE ZONE OF FINDELEN GLACIER, SWITZERLAND}

\author{
by
}

Melinda M. Brugman and Almut Iken

(Versuchsanstalt für Wasserbau, Hydrologie und Glaziologie, ETH-Zentrum, $\mathrm{CH}-8092$ Zürich, Switzerland)

\section{ABSTRACT}

Basal and englacial debris layers have been observed to coincide distinctly with the location of glacier thrust planes or shear zones, e.g. at Shoestring Glacier (Brugman and Meier 1980) and Variegated Glacier (Kamb and others 1985). They are also evident at Findelen Glacier. Field observations strongly suggest that the mechanics of debris-laden ice can be important for understanding the flow response of certain glaciers. In this paper the material properties of basal ice at Findelen Glacier are examined, as studied with the aid of ice-core drilling techniques.

Ice cores were taken from near the center line of Findelen Glacier during the summer of 1985, for the express purpose of characterizing the basal ice in terms of observed structures, composition and rheology. Related studies were simultaneously performed on bore-hole and surface strain-rate deformation (Iken and others, unpublished) and bore-hole resistivity (Schütz and Röthlisberger 1985). The ice core, retrieved from the deepest level possible (approximately $4 \mathrm{~m}$ above the bed), contained only a minor amount of fine rock debris. The presence of a debris-containing basal-ice zone is strongly suggested by the evidence that further hot-water drilling in the bore holes resulted in abraded drill stems and in the irregular progress of the drill for the few remaining meters to the glacier bed. Therefore, during 1986 samples of debris-laden basal ice were taken from several locations where the basal material was clearly exposed along lateral ice cliffs in the ablation area of the glacier.

Three distinct types of ice at Findelen Glacier were compared: clean bubbly coarse-grained ice taken from above the glacier bed, clean clear coarse-grained ice taken from 
within a few meters of the glacier bed at center line $(170 \mathrm{~m}$ depth), and debris-laden ice taken from the glacier bed at the lateral margin. Uniaxial compression experiments were conducted on the glacier-ice samples, using the triaxial testing apparatus of the IGB at ETH-Höngerberg. Laboratory studies of ice deformation were carried out under the guidance of A. Hofer, P. Hertzog and Professor Huder of IGB. Sample temperature, volume and strain-rate were monitored throughout each experiment. The confining pressure of each experiment was set at 4 bars (1 bar $=100 \mathrm{kPa})$. The deviatoric stresses applied were 1,2 and 4 bars, and testing temperatures were set at $-1.5,-0.8$ and $-0.4^{\circ} \mathrm{C}$ for each type of ice sampled (clean bubbly, clean clear, and debris-laden).

Preliminary results from experiments conducted on the clean bubbly and clean clear ice indicate that the mechanical behavior of the main bulk of the glacier is well represented by a power-law creep relationship with an exponent of about 4 . This value is in close agreement with independent results obtained from bore-hole-tilt studies (Iken and others, unpublished) and within the range of values cited in the published literature (Paterson 1983). The pre-exponential factor is not well represented by an Arrhenius-type relationship, and enhanced deformation is indicated for samples tested nearest the melting point. Additional laboratory and field studies on the ice-crystal fabrics and the behavior of the debris-laden ice are still in progress. In this paper the results of these investigations are discussed, with special emphasis on information gained from the ice-core drilling studies.

\section{REFERENCES}

Brugman M M, Meier M F 1981 Response of glaciers to the eruptions of Mount St. Helens. U.S. Geological Survey Professional Paper 1250: 743-756

Kamb W B and 7 others 1985 Glacier surge mechanism: 1982-1983 surge of Variegated Glacier, Alaska. Science 227(4686): $469-479$

Paterson W S B 1983 Deformation within polar ice sheets: an analysis of the Byrd Station and Camp Century borehole tilting measurements. Cold Regions Science and Technology 8(2): 165-179

\title{
TRACE ELEMENTS IN SIMULTANEOUSLY SAMPLED AEROSOL AND SNOW FROM THE ANTARCTIC PENINSULA
}

\author{
(Abstract) \\ by \\ Alan L. Dick \\ (British Antarctic Survey, High Cross, Madingley Road, Cambridge CB3 OET, England)
}

*Present address: Chemistry Division, DSIR, Private Bag, Petone, New Zealand

\begin{abstract}
Ultra-clean techniques have been used to collect a series of fresh surface-snow samples on Gipps Ice Rise, Larsen Ice Shelf $\left(68^{\circ} 48^{\prime} \mathrm{S}, 60^{\circ} 54^{\prime} \mathrm{W}\right)$ between 21 December 1984 and 12 February 1985. Aerosol samples were collected simultaneously on to pre-cleaned membrane filters to allow the direct comparison of trace-element levels in air and snow. Samples have been analysed by various techniques for cadmium, copper, lead, zinc, aluminium, calcium, potassium and sodium. For all elements, cross-sample concentration profiles have been obtained to support the data for snow samples.

The heavy-metal concentrations found in the surface snow were similar to those measured previously near Gomez
\end{abstract}

Nunatak in the Antarctic Peninsula. The mean aerosol concentrations found at Gipps Ice Rise were $\mathrm{Cd}$ : $0.06 \mathrm{pg} \mathrm{m}^{-3}, \mathrm{Cu}: 1.0 \mathrm{pg} \mathrm{m}^{-3}, \mathrm{~Pb}: 4.7 \mathrm{pg} \mathrm{m}^{-3}, \mathrm{Zn}: 6.1 \mathrm{pg} \mathrm{m}^{-3}$ These are the lowest concentrations measured so far in Antarctic aerosol.

The ratio of the snow concentration $\left(\mathrm{pg} \mathrm{g}^{-1}\right)$ to air concentration $\left(\mathrm{ng} \mathrm{m}^{-3}\right)$, known as the washout factor, has been calculated for each element and sampling period. The data show that, for the Antarctic Peninsula, the marine aerosol is more efficiently removed to the snow-pack than is the crustal aerosol. Heavy metals are least efficiently removed. This result suggests that the measurement of concentrations in snow and ice alone may lead to misinterpretation of atmospheric source strengths. 